\title{
Anatomical and Physiological Responses of Citrus megaloxycarpa Lush.: a Cryptic Species of Northeast India
}

\author{
Arun Jerang $^{1}$ (D) Sony Kumari ${ }^{1} \cdot$ Madhushmita Borthakur $^{1} \cdot$ Shahbaaz Ahmed $^{1}$
}

Accepted: 30 November $2021 /$

Published online: 6 January 2022

(c) The Author(s), under exclusive licence to Springer Science+Business Media, LLC, part of Springer Nature 2021

\begin{abstract}
In the historical mysteries and present pandemic situation, the use of citrus fruits makes it rise high among other fruits. Citrus has a significant role in dietary and medicinal purposes from time immemorial and widely acknowledged for its therapeutic properties. Citrus megaloxycarpa Lush. is an unspecified sibling of the citrus family. The present work highlights the biochemical, antimicrobial, and anticancerous potential of cryptic species indigenous to Northeast India. The research was done on peel; $\mathrm{P}\left(\mathrm{L}_{1}\right)$ and pulp; $\mathrm{Pu}\left(\mathrm{L}_{2}\right)$ extracts of ripe large and peel; $\mathrm{P}\left(\mathrm{L}_{1}\right)$ and pulp; $\mathrm{Pu}\left(\mathrm{L}_{2}\right)$ extracts unripe small varieties respectively. The extract of the $\mathrm{Pu}\left(\mathrm{L}_{2}\right)$ has the highest total soluble sugar $(9.174 \pm 0.006741 \mu \mathrm{g} / \mathrm{ml})$ whereas the extract of $\mathrm{P}\left(\mathrm{S}_{1}\right)$ demonstrated high protein concentration $(8.074 \pm 0.0567 \mu \mathrm{g} /$ $\mathrm{ml})$. The total carbohydrate content also varied in the extracts; the extract of $\mathrm{P}\left(\mathrm{L}_{1}\right)$ showed $(8.326 \pm 0.003844 \mu \mathrm{g} / \mathrm{ml}) . \mathrm{P}\left(\mathrm{L}_{1}\right)$ have high free amino acid content $(24.35 \pm 0.0225 \mu \mathrm{g} / \mathrm{ml})$ and high free fatty acid exhibited on $\mathrm{P}\left(\mathrm{L}_{2}\right)(0.3739 \pm 0.05774 \mu \mathrm{g} / \mathrm{ml})$. The total DPPH scavenging activity was compared for the extracts, where the extract of $\mathrm{Pu}\left(\mathrm{S}_{1}\right)$ exhibits highest activity $73.80 \%$ and 0.6577 of $\log \mathrm{IC} 50$ value. The highest total antioxidant capacity displays $150 \pm 0.333$ in $\mathrm{P}\left(\mathrm{L}_{1}\right)$. The MIC value was calibrated $(30 \%, 35 \%, 40 \%, 45 \%)(\mathrm{v} / \mathrm{v})$ and found to be maximum in $\mathrm{P}\left(\mathrm{L}_{2}\right)$ (0.695) and minimum in $\mathrm{P}\left(\mathrm{L}_{1}\right)(0.163)$ against Salmonella typhi and Escherichia coli. MTT assay showed highest viability rate of $94.32 \%$ and toxicity rate of $8.56 \%$ achieved on mouse lung cancerous cell. It is quite obvious from the present research that Citrus megaloxycarpa Lush. has a great scope at industrial level for developing therapeutic drugs.
\end{abstract}

Keywords Cryptic $\cdot$ Antioxidant $\cdot$ Antimicrobial $\cdot$ Anticancerous $\cdot$ Therapeutic

Arun Jerang

bjerang70@gmail.com

Sony Kumari

sonykumari_15@yahoo.com

Madhushmita Borthakur

mborthakur58@gmail.com

Shahbaaz Ahmed

shahbaazmohammad9678@gmail.com

1 Department of Applied Biology, School of Biological Sciences, University of Science and Technology, Meghalaya 793101, India 


\section{Introduction}

Citrus contains many phytochemicals such as vitamins, flavonoids, and phenolics compounds that are essential for carrying out different cellular activities to perform various physiological and enzymatic functions to prevent certain ailments in our busy lifestyle. Citrus peel was found to display extensive antimicrobial, antioxidant, and anticancer activity [2], 25. Phytochemicals found in citrus are having high nutritive value and help in inhibiting many disease-causing organisms. Citrus is believed to be originated from the tropical and sub-tropical regions of Asia and the Malay Archipelago and slowly spread across the world. The use of citrus is mentioned in Sanskrit and Chinese literature of early 800 BC [9]. Himalayan region and South China are known to be the place of origin for most citrus fruit,around 78 species of Rutaceae are found as a native of India [33]. Citrus is used as a traditional remedy from ancient times for restorative and ritual purpose around the globe. According to the World Health Organization (WHO), nearly 20,000 medicinal plants exist in 91 countries including 12 mega biodiversity countries [30]. Citrus sinensis is the most widespread grown crop in the state. Higher adaptability of citrus in different climatic conditions governs its successful growth rate in tropical, subtropical, and in some temperate regions of the world. Their nutritional and medicinal values have made them remarkably important. Lemon belongs to the family Rutaceae and is rich in sources like vitamin C, flavonoids, and essential oils which have antimicrobial and anticancer properties [18]. Citrus is used as an ethnic medicine in different parts of the world. Citrus medica fruits and leaves are used in asthma, diarrhoea, dysentery, fever, headache, intestinal disorder, jaundice, piles, pulmonary, skin disease, vomiting, worm infestation, etc. [15]. Citrus contains hesperidin, as well as diosmin, which is known to improve venous blood flow and promoting stability to the capillary vessels [10]10. Citrus jambhiri is used, citrus has many therapeutic attributes in levigating and incineration process of Ayurveda for purification, while [6]. Considerably Northeast India is paradise of many indigenous citrus species. It is considered one of the important fruit crops. Citrus crops are booming in Northeast Region due to its wide-ranging weather and rich soil condition, although production is lesser compare to other states. Northeast falls under different tropical and sub-tropical regions that support the growth of different citrus species. The chief citrus-growing belts in Northeast India are Meghalaya (Garo, Jaintia, Khasi, Dusha), Nagaland, Manipur, Arunachal Pradesh, and Assam. Wild flora of Northeast is rich in indigenous and semi-indigenous citrus fruit. Citrus is highly known for its nutritive value in Northeast India,the acidic nature of lemon makes it a preferable flavouring agent in dishes like vegetable, fish, meat, and salads, it is used in many Northeast Indian cuisines, particularly in Manipur peels of sour pummelo are used for cooking purpose. Citrus megaloxycarpa Lush. is a rare, endangered species of citrus found in the northeastern part of Indian.

The citrus crop is propagated by vegetative or seeds; it is of high importance to the horticultural community of Northeast India. Citrus medica, commonly known as Memang Narang by Garo tribe, are reportedly growing in the wild and virgin forest of Naga hills, in and around the national park, Kaziranga of Assam and in the Garo hills of Meghalaya [11]. Citrus latipes (Swingle) is found growing wild in sacred groves of Meghalaya. Some of the citrus fruits ingenious to Northeast region as reported by Bhattacharya and Shanta [3] are Citrus limon Brum, C. medica Linn., C. jambhiri Lush, C. inchangenis Swing, C. latipes Tanaka, C. macroptera Montr, C. assamensis, C. indica Tanaka, C. grandis L., and C. megaloxycarpa Lush. Kinnow ( $C$. nobilis and $C$. deliciosa) is a hybrid citrus between king orange and willow leaf Mandarin thriving in low lying areas of Northeast above sea level. 
The family Citrus is known for its diversified biochemical and pharmacologically potential activities. So, the present work aims in characterising and analysing various photochemical and physiological properties of unexplored variety of Citrus species, Citrus megaloxycarpa Lush. which is prevalent mostly in the northeastern part of India.

\section{Methods and Methodology}

\section{Sample Collection and Preparation}

The samples were collected from Pasighat, East Siang district of Arunachal Pradesh, located at $28.07^{\circ} \mathrm{N} 95.33^{\circ} \mathrm{E}$ with an average elevation of 502 feet. Collected samples were zipped and brought to laboratory condition and all the necessary morphological data was recorded. The peel and pulp extracts of ripening large citrus sample were indicated as $\mathrm{P}(\mathrm{L} 1)$ and $\mathrm{Pu}(\mathrm{L} 2)$ respectively, and unripe small peel and pulp extracts were indicated as $\mathrm{P}(\mathrm{S} 1)$ and $\mathrm{Pu}(\mathrm{S} 2)$ respectively. The samples were washed, peeled, and dried in hot air oven at a temperature of $40^{\circ} \mathrm{C}$ for $6-8$ days. A part of dried samples was stored at $-20^{\circ} \mathrm{C}$ for its further analysis.

\section{Sample Extraction}

The samples were extracted following the method described by Maruti et al. 2011 with little modifications. Ground dried sample (10 g) was extracted by stirring with $100 \mathrm{ml}$ of hexane at $150 \mathrm{rpm}$ at $25^{\circ} \mathrm{C}$ for $24 \mathrm{~h}$ using shaker incubator and then filtered through Whatman No.4 filter paper. The residue was again extracted with $100 \mathrm{ml}$ of hexane. The combined extracts were evaporated at $40^{\circ} \mathrm{C}$ to dryness and redissolved in hexane at a concentration of $100 \mathrm{mg} / \mathrm{ml}$ and stored at $4^{\circ} \mathrm{C}$ for further use.

\section{Determination of Biochemical Properties}

\section{Total Soluble Sugar}

Estimation of total soluble sugar was carried out with the process as described by Clegg [7] with minor modifications. The extract was mixed with sulphuric acid and Anthrone reagent. The solution was boiled until the reaction was completed. The solution was cooled and its absorbance was measured at $620 \mathrm{~nm}$.

\section{Total Soluble Protein}

Total soluble protein was estimated as per the method of Lowry et al [16] with minor modifications. The extract was treated with $5 \mathrm{ml}$ of solution $\mathrm{C}, 50 \mathrm{ml}$ solution A (2\% sodium carbonate in $0.1 \mathrm{~N} \mathrm{NaOH})+1 \mathrm{ml}$ solution $\mathrm{B}(0.5 \% \mathrm{CuSO} 4$ in $1 \%$ sodium potassium tartrate) followed by addition of $0.5 \mathrm{ml}$ Folin-Ciocalteu reagent. The mixture was mixed and incubated in dark for half an hour; then, absorbance was measured at $660 \mathrm{~nm}$. 


\section{Total Carbohydrate}

The estimation of total carbohydrate was carried out as per the method given by Clegg [7]. The extract was digested with $2 \mathrm{~N} \mathrm{HCl}$ and neutralized followed by centrifugation at $8000 \mathrm{rpm}$ for $5 \mathrm{~min}$. The supernatant was collected and treated with Anthrone reagent. The absorbance was read at $630 \mathrm{~nm}$.

\section{Free Amino Acid}

Free amino acid estimation was carried out using ninhydrin method with some slightest modification on the protocol by Moore and Stein [17]. The sample was mixed with the ninhydrin reagent and heated at a temperate of $85^{\circ} \mathrm{C}$ for $7 \mathrm{~min}$.

\section{Free Fatty Acid}

Estimation of free fatty acid was carried using the protocol of Cox and Pearson [5]. The sample was mixed with the neutral solvent and was titrated against $0.1 \mathrm{~N}$ potassium hydroxide. The acid value of the extract was calculated as follows:

\section{Acid value $(\mu \mathrm{g} \mathrm{KOH} / \mathrm{ml})=($ Titrate value $\times$ Normality of $\mathrm{KOH} \times 56.1) /$ Amount of sample}

\section{Antioxidant Assay}

\section{2, 2-Diphenyl-1-picrylhydrazyl (DPPH) Radical Scavenging Activity}

The scavenging activity of free radical 2, 2- diphenyl-1-picrylhydrazyl (DPPH) was monitored according to the method of Choi et al. [8]. Various concentrations of hexane extracts of the sample $(0.3 \mathrm{ml})$ were mixed with $2.7 \mathrm{ml}$ of solvent sample containing DPPH radicals. The mixture was left undisturbed in dark for $60 \mathrm{~min}$ until stable absorption was obtained. The DPPH radical reduction was monitored for the decreased absorption at 517 $\mathrm{nm}$. The radical-scavenging activity (RSA) was later calculated as a percentage of discoloured DPPH using the formula:

$$
\text { Scavenging activity }(\%)=[(\mathbf{A}-\mathbf{B}) / \mathbf{A}] \times 100
$$

where A is the absorbance of DPPH solution and B is the absorbance of DPPH when the extract was added.

The assays were carried out for triplicate and the mean value \pm standard deviations were accepted. IC50 65(50\% inhibition) was determined from the graph against the extracts where ascorbic acid was considered a standard.

\section{Total Antioxidant Capacity (TAC)}

The total antioxidant capacity is determined following the procedure described in Prieto et al. [26]. As per the protocol, $50 \mu \mathrm{l}$ of hexane extracts was taken and the volume was 
adjusted up to $500 \mu \mathrm{l}$ adding distilled water. To this mixture $4.5 \mathrm{ml}$ of phosphomolybedenum reagent was added and vortexed. The tubes were capped properly and incubated at $95^{\circ} \mathrm{C}$ for $90 \mathrm{~min}$. The absorbance was recorded at $695 \mathrm{~nm}$ against the blank and the control. Ascorbic acid $(0.25 \mathrm{mg} / \mathrm{ml})$ was used as standard. Concentration total antioxidant capacity was calculated using the following formula:

$$
\text { Total antioxidant } \operatorname{capacity}(\%)=[(\mathbf{A s}-\mathbf{A c}) /(\mathbf{A a a}-\mathbf{A c})] \times 100
$$

where Ac is the control absorbance, As is the sample absorbance, and Aaa is the ascorbic acid absorbance.

\section{Evaluation of Antimicrobial Activity}

This method involves the measurement of bioactivity of the test material used to induce effect on selected organism under controlled conditions. To carry out the experiment, glassware was sterilised in autoclave at $121^{\circ} \mathrm{C}$ at 15 Psi for $20 \mathrm{~min}$. The test organism used in this study includes both gram-negative and gram-positive bacteria (Escherichia coli, Pseudomonas aeruginosa, Salmonella typhi, and Bacillus subtilis). Series of dilution was prepared containing same amount of inoculated test organism, i.e. $1 \mathrm{ml}$. The test drug was prepared using serial dilution method (i.e. the concentration of drug in 1st tube is $45 \mu 1$, the 2nd tube will be $40 \mu \mathrm{l}$, and so on); distilled water is used tube serving as control. The tubes were incubated for $24 \mathrm{~h}$ at $37^{\circ} \mathrm{C}$. The tubes were observed for the growth of microorganism which is indicated by the turbidity in the tubes.

\section{Determination of Minimum Inhibitory Concentration (MIC)}

The minimum inhibitory concentration is the minimum concentration in which the test drug will inhibit growth of test microorganism. Turbidimetric assay was used to test the minimum inhibitory concentration of drug w.r.t the citrus extracts used against the microbial population by measuring turbidity of the suspension by Bansode and Chavan, where $9 \mathrm{ml}$ of nutrient broth is added into 6 culture tubes and $1 \mathrm{ml}$ of citrus was added to each tube with $0.1 \mathrm{ml}$ of microorganism being inoculated into each tube. The tubes were incubated overnight at $37^{\circ} \mathrm{C}$ and the development of turbidity is measured at $625 \mathrm{~nm}$ on U.V spectrophotometer.

\section{Cell Cytotoxicity Assay (MTT Assay)}

The test was outsourced and performed in Department of Biotechnology and Bio-engineering, Institute of Technology, Gauhati University. The method of [19] was followed for the cytotoxicity assay. Ten micolitres of MTT solution was added in each well except blank to get a final concentration of $0.5 \mathrm{mg} / \mathrm{ml}$ incubated at $37^{\circ} \mathrm{C}$ for $1-4 \mathrm{~h}$. The formazan crystals and triturate are dissolved by adding $100 \mu \mathrm{l}$ of solubilizing solution. Incubated at room temperature $\left(37^{\circ} \mathrm{C}\right)$ for $3 \mathrm{~h}$ to ensure complete solubilisation of formazan crystals, the absorbance was measured at $750 \mathrm{~nm}$. The cell viability is indicated by higher absorbance value, while lower value indicates cell cytotoxicity.

$$
\begin{aligned}
& \% \text { Viability }=(\text { Asample }- \text { ABlank }) /(\text { AControl }- \text { ABlank }) \times 100 \\
& \% \text { Cytotoxicity }=100-\% \text { Viability }
\end{aligned}
$$

where $\mathrm{A}=$ absorbance. 


\section{Result and Discussion}

The collected sample was morphologically diverse and largest of all citrus species found at an elevation 502 feet above sea level located at $28.07^{\circ} \mathrm{N} 95.33^{\circ} \mathrm{E}$, Pasighat, East Siang district, Arunachal Pradesh; fruits were globose and light green to pale yellow in colour, and moderately pear shaped and have bumpy fruit surface. Exocarp contains aromatic oil glands with thick mesocarp; carpel is small and contains no juicy vesicles or seeds. The sample fresh weight was $4.25 \mathrm{~kg}$ and $1.62 \mathrm{~kg}$ and size $36 \times 14(1 / 2) \times 7 \mathrm{~cm}$. The morphology of Citrus megaloxycarpa Lush. along with cross-section and appearance has been shown in Fig. 1. Over the past decade, a considerable amount of work has been done to study the various potential of citrus fruits. Citrus megaloxycarpa Lush. is a little-known sibling of genus Citrus and family Rutaceae with an unknown origin. This study was formulated for the assessment of biochemical and antioxidant activities of Citrus megaloxycarpa Lush. The statistics support bioactive compounds presence combined with antioxidant, antimicrobial, and anticancer activity that further emulates with the result obtained from different studies.

The highest representation of total soluble sugar (TSS) was $9.174 \pm 0.006741 \mu \mathrm{g} / \mathrm{ml}$ in pulp extract of ripening large sample $\mathrm{Pu}\left(\mathrm{L}_{1}\right)$ (Table 1), whereas Mbogo et al. [20] studied two varieties of Citrus sinensis species (Navel and Valencia) (11.4 $\pm 0.4,33.4 \pm 0.4$ ), these values clearly show higher level of total soluble sugar compared to the above sample.

The investigated value of total soluble protein ranges from $8.074 \pm 0.0567 \mu \mathrm{g} / \mathrm{ml} \mathrm{P}\left(\mathrm{L}_{1}\right)$ $-6.643 \pm 0.09074 \mu \mathrm{g} / \mathrm{ml}$. However, Ayona and Athira [1] confirm Citrus limonum to have $0.021 \pm 0.014 \mathrm{mg}$ followed by Citrus aurantium with $0.019 \pm 0.013 \mathrm{mg}$ that confirms the above studied citrus sample contains considerably less amount of total soluble protein.

Total carbohydrate was $8.326 \pm 0.003844 \mu \mathrm{g} / \mathrm{ml}$ on peel extract of ripening large sample; accordingly, Garcia et al. [12] study on Citrus unshiu Marc. leaves reported higher level of total carbohydrate content.

The observed value of free amino acid was $24.35 \pm 0.0225 \mu \mathrm{g} / \mathrm{ml}$ on peel extract of ripening large sample $\mathrm{P}\left(\mathrm{L}_{1}\right)$; however, Vandercook and Price [32] study on orange juice and citrus juice $(6.5 \pm 2.0,16.6 \pm 4.6 \mathrm{meq} / \mathrm{ml})$ exhibits higher value w.r.t to above result. Free fatty acid value of $373.9(\mu \mathrm{g} \mathrm{KOH} / \mathrm{ml})$ is reported in pulp extract of ripening large sample $\mathrm{Pu}\left(\mathrm{L}_{2}\right)$ (Table 1),reportedly, Caroline and Neuza [4] found to have free fatty acid of $0.27 \pm$ $0.03 \mathrm{a} \mathrm{meq} / \mathrm{kg}$ in Valencia orange that is predominantly higher in comparison to the values obtained in the above citrus sample.

(a)

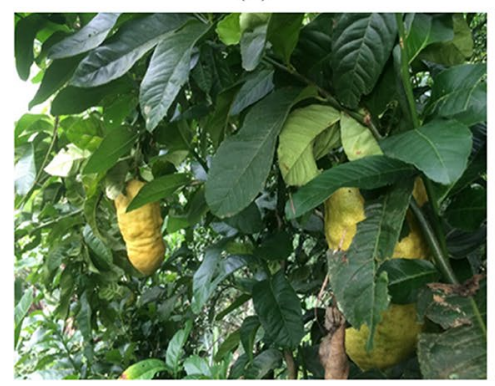

(b)

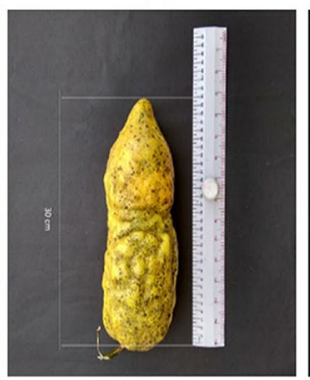

(c)

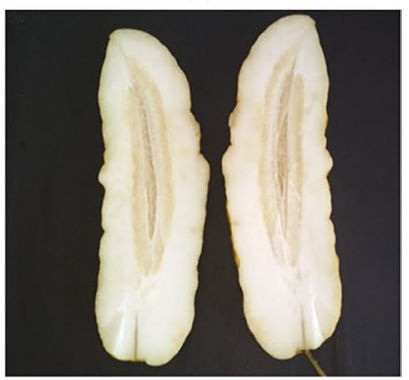

Fig. 1 Morphology and cross-section of Citrus megaloxycarpa Lush. 


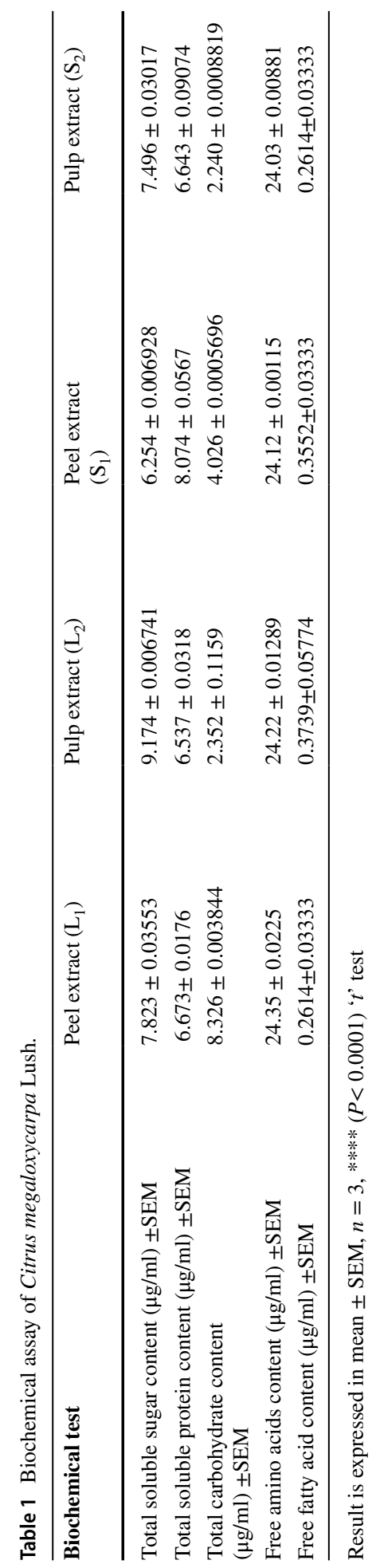


Table 2 IC50 DPPH scavenging activity of Citrus megaloxycarpa Lush.

\begin{tabular}{llll}
\hline Peel extracts $\left(\mathbf{L}_{\mathbf{1}}\right)$ & Pulp extract $\left(\mathbf{L}_{\mathbf{2}}\right)$ & Peel extract $\left(\mathbf{S}_{\mathbf{1}}\right)$ & Pulp extract $\left(\mathbf{S}_{\mathbf{2}}\right)$ \\
\hline $\log \mathrm{IC} 50=0.6527$ & $\operatorname{logIC} 50=0.6577$ & $\log \mathrm{IC} 50=0.5088$ & $\log \mathrm{IC} 50=0.5122$ \\
$\mathrm{IC} 50=89.9$ & $\mathrm{IC} 50=90.94$ & $\mathrm{IC} 50=64.54$ & $\mathrm{IC} 50=65.04$ \\
\hline
\end{tabular}

Result shown in $\%$ mean, $n=3$, **** (level of significance) $P<0.0001$ by ' $t$ ' test

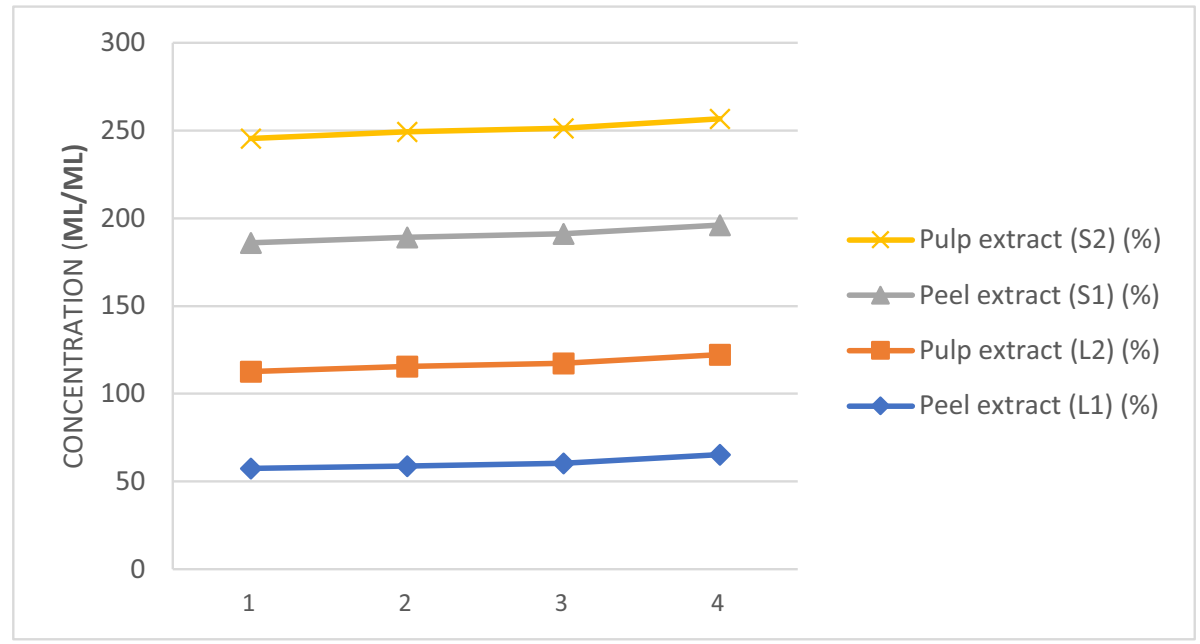

Fig. 2 DPPH free radical (\%) scavenging activity of Citrus megaloxycarpa Lush. extracts

The value of 2, 2-diphenyl-1-picrylhydrazyl (DPPH) scavenging activity was $73.80 \%$ in unripen peel extracts above all the extracts used (Table 2 and Fig. 2); by comparing the standard (ascorbic acid, 14\%), it is found that citrus extracts are having higher scavenging activity. Citrus reticulate shows $85 \%$ of scavenging activity [31] that reveals higher scavenging activity. The IC50 value was computed for all the samples using hexane extracts (Table 2) where unripen peel extracts depict lowest IC50 (64.54) that clearly indicates the increase in scavenging activity with comparison to IC50 obtained in Sheila et al. [22] study of $107.48 \mu \mathrm{g} / \mathrm{ml}$ on acetone extract and $278.24 \mu \mathrm{g} / \mathrm{ml}$ in methanolic extract.

The value of total antioxidant capacity (Fig. 3) was recorded as $150 \pm 0.333$ in peel extract $\left(\mathrm{L}_{1}\right)$, whereas the value obtained in Prakash et al. [21] study in Citrus aurantium peel extract was $18.2 \pm 1.4$ that is significantly lower in comparison to above obtained value.

Thus, the observed result shows MIC at 45\%, 35\%, and 30\% (v/v) for Salmonella typhi, and $40 \%$ (v/v) for Pseudomonas aeruginosa, Escherichia coli, and Bacillus subtilis, and at $35 \%$ for Salmonella typhi as represented in (Fig. 4 and Table 3) where each curve corresponds to the MIC of different organisms with respect to the standard antibiotic used; highest susceptibility was observed in Escherichia coli followed by Salmonella typhi and Pseudomonas aeruginosa. In conclusion with the experimental data obtained by Oikeh et al. [24], lime juice shows promising result against Pseudomonas aeruginosa (12.5 $\mu \mathrm{g} / \mathrm{ml})$. 


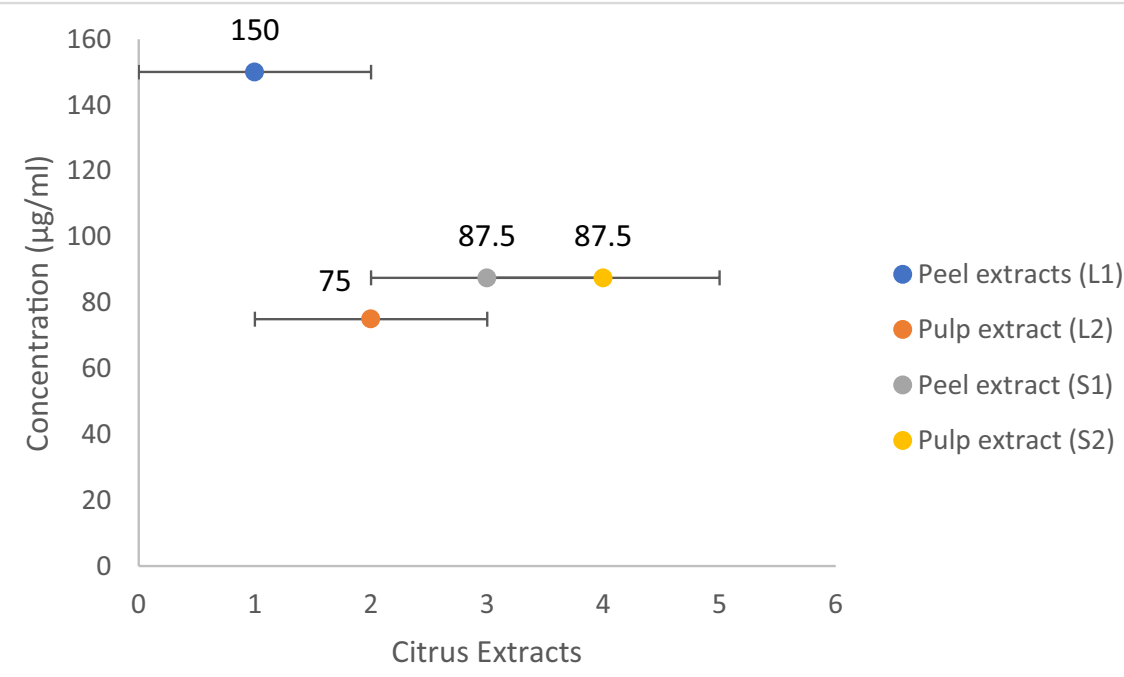

Fig. 3 Total antioxidant capacity (\%) of Citrus megaloxycarpa Lush. extracts

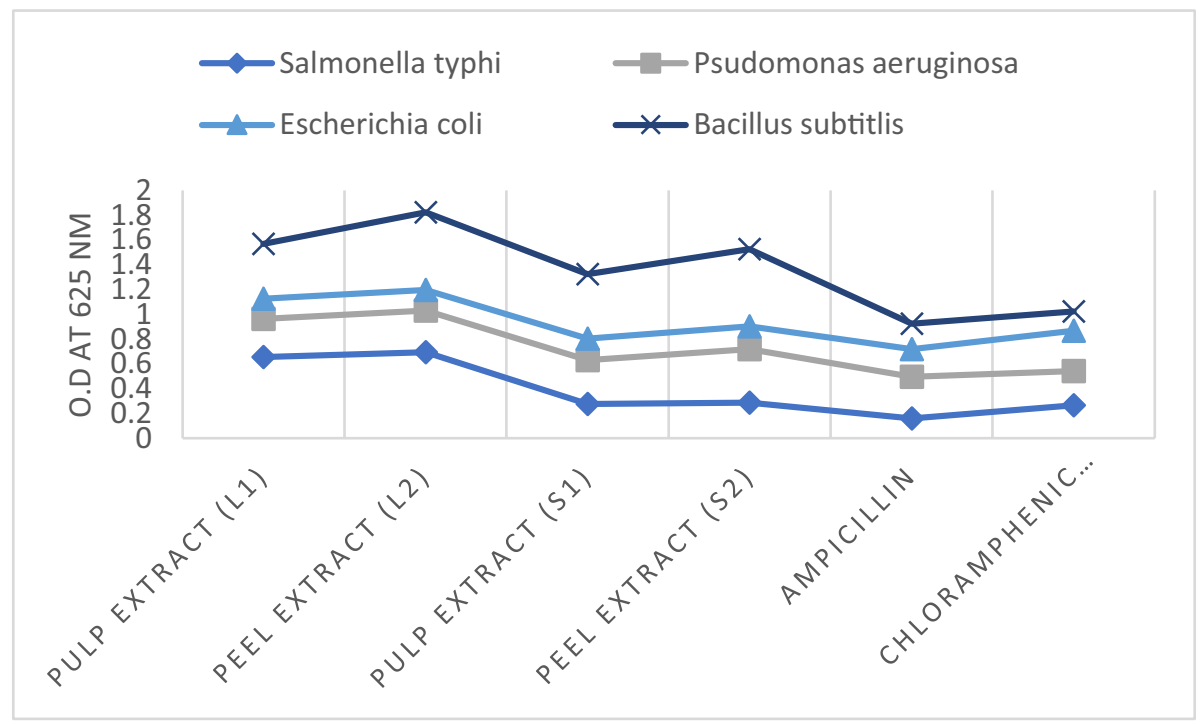

Fig. 4 Minimum inhibitory concentration of citrus extracts vs standard antibiotic used

MTT (3-(4,5-dimethylthiazol-2-yl)-2,5-diphenyl tetrazolium bromide) assay exhibit cell viability and cytotoxcity rate of $94.32-5.67 \%$ for ripening peel $\mathrm{P}\left(\mathrm{L}_{1}\right)$ and pulp $\mathrm{Pu}\left(\mathrm{L}_{2}\right)$ extract (Table 4$)$, whereas unripen small sample achieved lower viability rate 
Table 3 Inhibitory concentration of different standards used

Table 4 Cell cytotoxicity (MTT assay) result

\begin{tabular}{lll}
\hline Antibiotic & Organisms & $\begin{array}{l}\text { O.D at } \mathbf{6 2 5} \\
\mathbf{n m}(\mathbf{1 0 0} \boldsymbol{\mu l})\end{array}$ \\
\hline Ampicillin & Salmonella typhi & 0.162 \\
& Psdomonas aeruginosa & 0.336 \\
& Escherichia coli & 0.221 \\
& Bacillus subtilis & 0.205 \\
Chloramphenicol & Salmonella typhi & 0.267 \\
& Psudomonas aeruginosa & 0.275 \\
& Escherichia coli & 0.328 \\
& Bacillus subtilis & 0.154 \\
\hline
\end{tabular}

\begin{tabular}{lll}
\hline Test sample & \% Viability & \% Cytotoxicity \\
\hline Pulp extract $\left(\mathrm{L}_{1}\right)$ & 94.32 & 5.67 \\
Peel extract $\left(\mathrm{L}_{2}\right)$ & 94.32 & 5.67 \\
Pulp extract $\left(\mathrm{S}_{1}\right)$ & 91.44 & 8.56 \\
Peel extract $\left(\mathrm{S}_{2}\right)$ & 92.32 & 7.68 \\
\hline
\end{tabular}

$(91.44 \%, 92.32 \%)$ and high cytotoxicity rate $(8.56 \%, 7.68 \%)$ in comparison to ripening sample; MTT assay for Citrus megaloxycarpa Lush. is novel and reported in this study.

\section{Conclusion}

The phytochemical analysis of Citrus megaloxycarpa Lush. provides evidence of its potency with the values obtained in peel and pulp extracts. The obtained value is incorporated in this conclusion to interpret its therapeutical and pharmacological potential. Thus, the total soluble sugar value was $9.174 \pm 0.006741 \mu \mathrm{g} / \mathrm{ml}$, whereas the total protein concentration of $8.074 \pm 0.0567 \mu \mathrm{g} / \mathrm{ml}$. The total carbohydrate content was as high as $8.326 \pm 0.003844 \mu \mathrm{g} / \mathrm{ml}$ above all the samples. Free amino acid content was $24.35 \pm 0.0225 \mu \mathrm{g} / \mathrm{ml}$ with high value of free fatty acid $(0.3739 \pm 0.05774 \mu \mathrm{g} / \mathrm{ml})$; these biochemical activities signify its potential in conventional drug therapy. The total DPPH scavenging activity displays maximum activity of $73.80 \%$ with $\log$ IC50 of 0.6577 and total antioxidant capacity value of $150 \pm 0.333 \mu \mathrm{g} /$ $\mathrm{ml}$; this demonstrates that it can be used for improving the immune response of the body against various ailments, such as COVID-19. The MIC conducted among the citrus extract was found to have maximum inhibiting activity in Salmonella typhi (0.695) and minimum against Escherichia coli (0.163); thus, the susceptibility induced by antimicrobial activity of citrus extract will be potential breakthrough in treating enteric organism infections; subsequently this citrus extracts can be a capable alternative in treating cancer as MTT assay exhibits viability rate of $94.32 \%$ and toxicity rate of $8.56 \%$ in the mouse lung cancerous cell. Unlike other states Northeast India is rich in diverse species of wild citrus fruit; amid those Citrus megaloxycarpa Lush. is exceptional. The species showed a wide range of properties in terms of nutritional, antioxidant, antimicrobial, and anticancer activities. The potency of this citrus extract is articulated through the values obtained. Despite this plant having an enormous potential, it is still an endangered species of citrus. Making available 
data about its significance will vastly intercept species extinction; furthermore, introducing the market into different sectors will help in the upliftment of the socio-economic condition of the ethnic tribe of the region.

Acknowledgements The authors hereby acknowledge University of Science and Technology, Meghalaya, for providing the entire requisite needed for the completion of this work. The authors also acknowledge GUIST, Department of Biotechnology and Bioengineering, for carrying out the anti-cancerous assays.

Author Contribution Mr. Arun jerang and Shahbaaz Ahmed have meticulously carried out biochemical and antioxidant assay whereas the anticancer study was outsourced and performed in Guwahati University. The work was completed under the guidance of Dr. Sony kumari, and Dr. Madushmita Borthakur supportively helped in the collection of data and compiling it.

Availability of Data and Materials The findings and relevant data along with material have been made available for publishing in the journal Applied Biochemistry and Biotechnology.

\section{Declarations}

Ethical Approval Not applicable.

Consent to Participate The authors give their full consent to participate, with regard to the underlining procedure for journal Applied Biochemistry and Biotechnology.

Consent to Publish The authors give their full pledge consent to journal Applied Biochemistry and Biotechnology for publishing this piece of work for the future prospects of researchers and Institutional bodies.

Competing Interests The authors declare no competing interests.

\section{References}

1. Ayona, J., \& Athira, U. (2017). Comparative analysis of nutritional and anti-nutritional components of selected citrus fruit species. International Journal for Research in Applied Science and Engineering Technology, 5(10), 309-312. https://doi.org/10.22214/ijraset.2017.10047

2. Burt, S. (2004). Essential oils: Their antibacterial properties and potential applications in foods: A review. The International Journal of Food Microbiology, 94(3), 223-253. https://doi.org/10.1016/j. ijfoodmicro.2004.03.022

3. Bhattacharya, S. C., \& Dutta, S. (1956). Classification of citrus fruits of Assam. Indian council of agricultural research. Scientific Monograph, 20, 110.

4. Caroline, P. M. A., \& Neuza, J. (2013). Physico chemical characterization of seed oils extracted from oranges (citrus sinensis). Food Science and Technology Research, 19(3), 409-415. https://doi.org/10. 3136/fstr. 19.409

5. Cox, H. E., \& Pearson, D. (1962). The chemical analysis of foods (p. 420). Chemical publishing Co Inc.

6. Chaudhari, S. Y., Galib, R., \& Prajapati, P. (2016). Ethno medicinal values of Citrus genus: A review. Medical Journal of Dr DY Patil Vidyapeeth, 9(5), 560-565. https://doi.org/10.4103/09752870.192146

7. Clegg, K. M. (1956). The application of the anthrone reagent to the estimation of starch in cereals. Journal of the science of food and Agriculture, 7(1), 40-44. https://doi.org/10.1002/jsfa.2740070108

8. Choi, H. Y., Jhun, E. J., Lim, B. O., Chung, I. M., Kyung, S. H., \& Park, D. K. (2000). Application of flow injection-Chemiluminescence to the study of radical scavenging activity in plants. Phytotherapy Research, 14(4), 250-3.

9. Dorian QF, Cristina C, Eleanor Kingwell B, Ling Q and Alison W (2017) Charred pummelo peel, historical linguistics and other tree crops: Approaches to framing the historical context of early Citrus cultivation in East, South and Southeast Asia. @Publications du Centre Jean Bérard. Available from https://books.openedition.org; https://doi.org/10.4000/books.pcjb.2107. Accessed 14 Aug 2021. 
10. Economos, C., \& Clay, W. (2012). Nutritional and health benefits of citrus fruits. Food and Agriculture Organization. Available online: ftp://ftp.fao.org/docrep/fao/X2650T/X2650t03.pdf. Accessed 1 Oct 2018.

11. Ghosh, S. P. (1985). Horticulture in North Eastern India (pp. 225-230). Associated Publishing Company.

12. Garcia, L. A., Fornes, F., \& Guardiola, J. L. (1995). Leaf carbohydrates and flower formation in citrus. The Journal of the American Society for Horticultural Science, 120(2), 222-227.

13. Hansen, M. B., Nielsen, S. E., \& Berg, K. (1989). Re-examination and further development of a precise and rapid dye method for measuring cell growth/cell kill. The Journal of Immunological Methods, 119, 203-210. https://doi.org/10.1016/0022-1759(89)90397-9

14. Hedge, J. E., \& Hofreiter, B. T. (1962). Methods in Carbohydrate Chemistry (17th ed.). (Whistler R.L and Be Miller. J.N) Academic Press.

15. Khalid, H., Nisar, M., Majeed, A., Nawaz, K., \& Bhatti, K. (2014). Ethnomedicinal survey for important plants of Jabalpur jattan District Gujrat, Punjab, Pakistan. International Journal Ethnobotanical Research, 14, 807-25.

16. Lowry, O. H., Rosebrough, N. J., Farr, A. L., \& Randall, R. J. (1951). Protein measurement with the Folin phenol reagent, 193(1), 265-275. https://www.jbc.org/article/S0021-9258(19)52451-6/pdf. Accessed 11 Aug 2019.

17. Moore, S., \& Stein, W. H. (1948). Photometris ninhydrin method for use in the chromatography of amino acids. The Journal of Biological Chemistry, 176, 367-388.

18. Rattanpal HS, Gurteg S, Sandeep S, Anita A (2017). Citrus cultivation in Punjab (First Edition). Punjab Agriculture University Ludhiana. ISBN 978-93-86267-15-3

19. Mosmann, T. (1983). Rapid colorimetric assay for cellular growth and survival: Application to proliferation and cytotoxicity assays. The Journal of Immunological Methods, 65, 55-63.

20. Mbogo PG, Egid BM, Othman CC (2010) Post harvest changes in physico-chemical properties and levels of some inorganic elements in off vine ripened orange (Citrus sinensis) fruits cv (Navel and Valencia) of Tanzania. African Journal of Biotechnology. 9(12). https://doi.org/10.5897/AJB10.1781

21. Prakash, J. D., Prakash, J., \& Lakshmi, A. J. (2016). Antioxidant properties of fresh and processed Citrus aurantium fruit. Cogent Food \& Agriculture, 1(2), 1184119. https://doi.org/10.1080/23311932. 2016.1184119

22. Sheila, J., Sarah, J. M., Priyadarshini, S., Sivaraj, C., \& Arumugam, P. (2017). Antioxidant and antibacterial activities of Beta vulgaris L. peel extracts. International Journal of Pharma Research and Health Sciences, 5(6), 1974-79. https://doi.org/10.21276/ijprhs.2017.06.14

23. Stanford, M., \& William, H. S. (1948). Photometric ninhydrin method for use in the chromatography of amino acid. The Journal of Biological Chemistry, 176, 367-88.

24. Oikeh, E. I., Ehimwenma, S., Omoregie, F. E., \& Oviasogie, K. O. (2016). Phytochemical, antimicrobial, and antioxidant activities of different citrus juice concentrates. International Journal of Food Science and Nutrition (Wiley Online Library), 4(1), 103-109.

25. Ortuno, A. A., Baidez, P., Gomez, M. C., Arcas, I., Porras, A. G., \& Del, R. J. A. (2006). Citrus paradise and citrus sinensis flavonoids: Their influence in the defence mechanism against penicillium digitatum. International Journal of Food Chemistry, 98, 351-358. https://doi.org/10.1016/j.foodchem. 2005.06.017

26. Prieto, P., Pineda, M., \& Aguilar, M. (1999). Spectrophotometric quantitation of antioxidant capacity through the formation of a phosphomolybdenum complex: specific application to the determination of vitamin E. International Journal of Analytical Biochemistry., 269(2), 337-41. https://doi.org/10.1006/ abio.1999.4019

27. Pallavi, M., Ramesh, C. K., Krishna, V., Sameera, P., \& Nanjunda, S. L. (2017). Qualitative phytochemical analysis and antioxidant activities of some citrus fruits of South India. Asian J Pharmaceutical and Clinical Research., 10(12), 198-05. https://doi.org/10.22159/ajpcr.2017.v10i12.20912

28. Roger, G. D. (2002). Encyclopaedia of medicinal plants, Education and Health library editorial safeliz S.L. Spain. 1, 153-154, 265-267.

29. Suja, D., Bupesh, G., Nivya, R., Mohan, V., Ramasamy, P., Ns, Muthiah, et al. (2017). Phytochemical screening, antioxidant, antibacterial activities of citrus limon and citrus sinensis peel extracts. International Journal of Pharmacognosy \& Chinese Medicine., 1(2), 1-7.

30. Sasidharan, S., Saravanan, D., Sundram, K. M., Latha, L. Y., \& Chen, Y. (2012). Extraction, isolation and characterization of bioactive compounds from plants extracts. The African Journal of Traditional, Complementary and Alternative Medicines, 8(1), 1-10.

31. Vinita, D. A., \& Nancy, S. P. (2016). Evaluation of skin anti-aging potential of citrus reticulata blanco peel. In J India pharmacognosy Res., 8(3), 160-168. https://doi.org/10.4103/0974-8490.182913 
32. Vandercook, C. E., \& Price, R. L. (1972). The application of amino acid composition to the characterization of citrus juice. Journalof Food Science (Wiley online library)., 37(3), 384-386. https://doi.org/ 10.1111/j.1365-2621.1972.tb02644.x

33. YuQiu, L., Emily, H., \& Sherry, A. T. (2012). History, global distribution, and nutritional importance of citrus fruits. Wiley Online Library (Comprehensive Reviews in Food Science and Food Safety)., 11(6), 530-545. https://doi.org/10.1111/j.1541-4337.2012.00201.x

Publisher's Note Springer Nature remains neutral with regard to jurisdictional claims in published maps and institutional affiliations. 